\title{
The Antarctic ice core chronology (AICC2012): an optimized multi-parameter and multi-site dating approach for the last 120 thousand years
}

\author{
D. Veres ${ }^{1,2}$, L. Bazin ${ }^{3}$, A. Landais ${ }^{3}$, H. Toyé Mahamadou Kele ${ }^{4}$, B. Lemieux-Dudon ${ }^{4}$, F. Parrenin ${ }^{1}$, P. Martinerie ${ }^{1}$, \\ E. Blayo $^{4}$, T. Blunier ${ }^{5}$, E. Capron ${ }^{6}$, J. Chappellaz ${ }^{1}$, S. O. Rasmussen ${ }^{5}$, M. Severi ${ }^{7}$, A. Svensson ${ }^{5}$, B. Vinther ${ }^{5}$, and \\ E. W. Wolff ${ }^{6}$ \\ ${ }^{1}$ UJF - Grenoble 1/CNRS, Laboratoire de Glaciologie et Géophysique de l'Environnement (LGGE), UMR5183, \\ CNRS/INSU - Grenoble, 38041, France \\ ${ }^{2}$ Institute of Speleology, Romanian Academy, 400006 Cluj-Napoca, Romania \\ ${ }^{3}$ Laboratoire des Sciences du Climat et de l'Environnement, UMR8212, CNRS - Gif sur Yvette, France \\ ${ }^{4}$ Laboratoire Jean Kuntzmann, Grenoble, France \\ ${ }^{5}$ Centre for Ice and Climate, Niels Bohr Institute, University of Copenhagen, Copenhagen, Denmark \\ ${ }^{6}$ British Antarctic Survey, Cambridge, UK \\ ${ }^{7}$ Department of Chemistry Ugo Schiff, University of Florence, Florence, Italy
}

Correspondence to: D. Veres (daniel.veres@lgge.obs.ujf-grenoble.fr, danveres@hasdeu.ubbcluj.ro), L. Bazin (lucie.bazin@1sce.ipsl.fr), and A. Landais (amaelle.landais@1sce.ipsl.fr)

Received: 15 November 2012 - Published in Clim. Past Discuss.: 3 December 2012

Revised: 24 June 2013 - Accepted: 25 June 2013 - Published: 1 August 2013

\begin{abstract}
The deep polar ice cores provide reference records commonly employed in global correlation of past climate events. However, temporal divergences reaching up to several thousand years (ka) exist between ice cores over the last climatic cycle. In this context, we are hereby introducing the Antarctic Ice Core Chronology 2012 (AICC2012), a new and coherent timescale developed for four Antarctic ice cores, namely Vostok, EPICA Dome C (EDC), EPICA Dronning Maud Land (EDML) and Talos Dome (TALDICE), alongside the Greenlandic NGRIP record. The AICC2012 timescale has been constructed using the Bayesian tool Datice (Lemieux-Dudon et al., 2010) that combines glaciological inputs and data constraints, including a wide range of relative and absolute gas and ice stratigraphic markers. We focus here on the last $120 \mathrm{ka}$, whereas the companion paper by Bazin et al. (2013) focuses on the interval 120-800 ka.

Compared to previous timescales, AICC2012 presents an improved timing for the last glacial inception, respecting the glaciological constraints of all analyzed records. Moreover, with the addition of numerous new stratigraphic markers and improved calculation of the lock-in depth (LID) based on
\end{abstract}

$\delta^{15} \mathrm{~N}$ data employed as the Datice background scenario, the AICC2012 presents a slightly improved timing for the bipolar sequence of events over Marine Isotope Stage 3 associated with the seesaw mechanism, with maximum differences of about $600 \mathrm{yr}$ with respect to the previous Datice-derived chronology of Lemieux-Dudon et al. (2010), hereafter denoted LD2010. Our improved scenario confirms the regional differences for the millennial scale variability over the last glacial period: while the EDC isotopic record (events of triangular shape) displays peaks roughly at the same time as the NGRIP abrupt isotopic increases, the EDML isotopic record (events characterized by broader peaks or even extended periods of high isotope values) reached the isotopic maximum several centuries before.

It is expected that the future contribution of both other long ice core records and other types of chronological constraints to the Datice tool will lead to further refinements in the ice core chronologies beyond the AICC2012 chronology. For the time being however, we recommend that AICC2012 be used as the preferred chronology for the Vostok, EDC, EDML and TALDICE ice core records, both over the last glacial cycle 
(this study), and beyond (following Bazin et al., 2013). The ages for NGRIP in AICC2012 are virtually identical to those of GICC05 for the last $60.2 \mathrm{ka}$, whereas the ages beyond are independent of those in GICC05modelext (as in the construction of AICC2012, the GICC05modelext was included only via the background scenarios and not as age markers). As such, where issues of phasing between Antarctic records included in AICC2012 and NGRIP are involved, the NGRIP ages in AICC2012 should therefore be taken to avoid introducing false offsets. However for issues involving only Greenland ice cores, there is not yet a strong basis to recommend superseding GICC05modelext as the recommended age scale for Greenland ice cores.

\section{Introduction}

The last climatic cycle (last 120 thousand years before present, hereafter ka BP, with present defined as $1950 \mathrm{AD}$ in our study) of the Earth's climate history represents one of the best-studied periods in paleoclimatology, owing to the exceptional insights it provides into several windows of past climate change, all significantly different from each other (Grootes et al., 1993; Masson-Delmotte et al., 2005; Wolff et al., 2010). These include for example the glacial inception and abrupt centennial-to-millennial stadial and interstadial climate variability, the cryosphere expansion that culminated into full glacial climates during Marine Isotope Stages (MIS) 4 and 2, followed by the dynamic environmental changes of the last termination (NGRIP members, 2004; EPICA Community Members, 2004, 2006; Pedro et al., 2011).

From the moment of their discovery decades ago in Greenland ice core records (Dansgaard et al., 1982, 1984), centennial-to-millennial scale climate oscillations, known also as Dansgaard-Oeschger (DO) events, have been the subject of intense research to document their nature, amplitude of change, and links with paleoenvironmental and lowlatitude records (e.g. Grootes et al., 1993; NGRIP members, 2004; Landais et al., 2004; Masson-Delmotte et al., 2005; Huber et al., 2006; Loulergue et al., 2008; Wolff et al., 2010). The DO events, most clearly observed in the North Atlantic region, are recorded in Greenland ice cores as abrupt temperature increases of $8-16^{\circ} \mathrm{C}$ in a few centuries from cold periods (Greenland stadials, GS) to warm periods (Greenland interstadials, GI) (Severinghaus et al., 1998; Lang et al., 1999; Landais et al., 2004; Huber et al., 2006), while the coolings are more gradual. Associated with the abrupt temperature increases in Greenland, the so-called Antarctic Isotopic Maxima (AIM) have been observed in Antarctic ice core records (e.g. EPICA Community Members, 2006). In the Antarctic records however, the water isotope variability is characterized by more gradual temperature changes (approximately $2{ }^{\circ} \mathrm{C}$ per millennium), with Greenland stadials generally corresponding to periods of increasing isotope ratios in Antarctica (Blunier et al., 1998; Blunier and Brook, 2001; Jouzel et al., 2007; Kawamura et al., 2007; Wolff et al., 2009; Barker et al., 2011). In addition to the ice core evidence, a range of proxies in various types of paleoclimate archives host the imprint of these climate oscillations (Voelker, 2002), with the most chronologically significant constraints linked to radiocarbon-dated varved records (e.g. Bronk Ramsey et al., 2012), marine series (Lisiecki and Raymo, 2005 and references therein; Waelbroeck et al., 2008), or absolutely dated cave carbonate records (Drysdale et al., 2007; Wang et al., 2008; Cheng et al., 2009; Fleitmann et al., 2009; Boch et al., 2011).

Still, many questions remain open on the mechanisms and feedbacks within the climate system that were behind the generation and propagation of these events. Such understanding would be greatly facilitated if the regional synchronicity of change and timing of events (Blaauw et al., 2010; Braun et al., 2011; Klauenberg et al., 2011) could be tested with respect to the contrasting thermo-climatic relationship between the polar regions as predicted by the bipolar seesaw hypothesis (Stocker and Johnsen, 2003; Steig et al., 1998; Pedro et al., 2011; Barker et al., 2011; Stenni et al., 2011; Buiron et al., 2012). Advancements in the absolute dating and relative synchronization of records are thus of primary importance for paleoclimatic archives (Blockley et al., 2012 and references therein), including ice cores (Parrenin et al., 2004, 2007, 2012a, 2013; Kawamura et al., 2007; Svensson et al., 2008; Lemieux-Dudon et al., 2010).

A significant issue when dealing with ice cores, however, is that two time-depth relationships must be assessed, one concerning the ice-phase (water isotopes, particulates and chemical impurities, etc.) and one for the gas-phase related proxies $\left(\mathrm{CO}_{2}, \mathrm{CH}_{4}\right.$, air isotopes, etc.). This particularity arises from the fact that at any depth, the entrapped air is always younger than the surrounding ice (Sowers et al., 1992 and references therein). This age difference, called $\Delta$ age, reflects the fact that air is isolated from the atmosphere only at 50-120 $\mathrm{m}$ under the ice sheet surface, where firn progressively reaches the density of ice. Knowing the temporal evolution of this lock-in depth (hereafter LID) for each ice core is therefore essential for establishing reliable links between ice and gas chronologies. Classically, estimating LID was based on firn densification models forced by estimates of past accumulation rate and temperature changes (e.g. Schwander et al., 1997; Arnaud et al., 2000; Goujon et al., 2003). However, studies have shown that firn densification models may provide inaccurate constraints that result in overestimating the glacial LID and hence $\Delta$ age in remote sites of East Antarctica where temperature and accumulation rates, particularly during glacial times, were very low (Loulergue et al., 2007; Parrenin et al., 2012b, 2013). For such settings, the $\delta^{15} \mathrm{~N}$ of $\mathrm{N}_{2}$ in the ice-entrapped air, linearly linked to the height of the firn diffusive zone, gives an alternative estimate of LID. Indeed, for remote sites of East Antarctica, the depth of the firn diffusive zone deduced from 
$\delta^{15} \mathrm{~N}$ of $\mathrm{N}_{2}$ is systematically lower by up to $40 \mathrm{~m}$ than the LID deduced from firnification models (Caillon et al., 2003; Dreyfus et al., 2007). By using a compilation of ice and gas stratigraphic markers from three Antarctic ice cores, Parrenin et al. (2012b) have indeed shown that over the last deglaciation at EPICA Dome C (EDC), the $\delta^{15} \mathrm{~N}$ of $\mathrm{N}_{2}$ gives a more reliable estimate of LID than firn densification modelling. Following on these arguments, and assuming that the convective zone at the top of the firn did not increase significantly during glacial periods, the $\delta^{15} \mathrm{~N}$ of $\mathrm{N}_{2}$ can thus be used alternatively to reconstruct past LID variations, with lower LID and hence $\Delta$ age over glacial periods than those suggested by firn densification models (Capron et al., 2013; Parrenin et al., 2013).

Here we report on the development of the common timescale AICC2012-Antarctic Ice Core Chronology 2012 over the last glacial period (0-120 ka BP) constructed for four Antarctic, Vostok, EDC, EPICA Dronning Maud Land (EDML) and Talos Dome (TALDICE), and one Greenland (NGRIP) ice cores. New developments over the period 120$800 \mathrm{ka}$ are being treated in the companion paper of Bazin et al. (2013). In the following, we first describe the initial ice core chronologies and associated dating constraints that have been implemented in AICC2012. Then, we discuss the numerous stratigraphic markers included in the inverse modelling analysis, which strongly constrain the relative timing of Greenland and Antarctic records over the last glacial period. Finally, we present some examples of the absolute and relative dating implications of the new chronology over the last glacial inception, and for the bipolar sequence of events associated with the seesaw mechanism over middle MIS 3 , respectively. Note that the Supplementary Online Material (SOM) presents common material (methodology and the AICC2012 timescale) for both this work and that of Bazin et al. (2013).

\section{The ice core records analyzed}

Ice cores recovered from high accumulation settings, such as the Summit Greenland or the coastal Antarctic regions, allow for reliable chronological constraints based on annual or subannual layer counting backed by high-resolution glaciochemical and impurity records (Legrand and Mayewski, 1997; Rasmussen et al., 2006; Svensson et al., 2008, 2013). The latter parameters also allow for the identification of common stratigraphic markers that have potential in securely linking records (Zielinski, 2000; Rasmussen et al., 2008; Wolff et al., 2009; Parrenin et al., 2012a), independently of climate modulated proxies such as water isotopes frequently used in data comparison (Grootes et al., 1993; Dahl-Jensen et al., 1998; Masson-Delmotte et al., 2005; Jouzel et al., 2007). The Greenland ice records, although providing exceptional resolution, are limited on a temporal scale and generally do not extend beyond MIS 5 (NGRIP Members, 2004). On the other hand, most Antarctic records, particularly the ones spanning several glacial-interglacial cycles, still rely mainly on glaciological modelling, tuning to orbital parameters, or matching to other dated records for deriving age constraints (Petit et al., 1999; Parrenin et al., 2001, 2004, 2007; Ruth et al., 2007; Kawamura et al., 2007).

We present below a short overview of the original timescales of the ice cores included in the building of the AICC2012 chronology; NGRIP, Vostok, EDC, and EDML have been already synchronized in the LD2010 timescale over the last $50 \mathrm{ka}$. Subsequently, the TALDICE chronological framework was also built using the Datice tool as discussed in Buiron et al. (2011).

\subsection{NGRIP and the composite Greenlandic ice core timescale GICC05}

The GICC05 composite timescale provides the most accurate annual chronological constraints for the Greenland ice cores up to $60.2 \mathrm{ka}$ BP. It has been constructed by annual layer counting using water isotopic data from DYE-3, GRIP and NGRIP from present and back to $7.9 \mathrm{ka}$ (Vinther et al., 2006), detailed glaciochemical data from GRIP and NGRIP for the last termination (Rasmussen et al., 2006), and similar parameters aided by visual stratigraphy records back to $60.2 \mathrm{ka}$ BP (Svensson et al., 2008). Because of the cumulative nature of errors when counting annual layers, the relative maximum counting error (at $2 \sigma$ ) of the number of layers are in the order of $2-4 \%$ for late MIS 3 and MIS 2, but exceed $5 \%$ for the early MIS 3 interstadials GI-13 to GI-17, although the GICC05 absolute age uncertainties (at $1 \sigma$ ) remain below $2.2 \%$.

For NGRIP record we employed the GICC05 composite timescale for the last $60 \mathrm{ka} \mathrm{BP}$, including the accumulation rate estimates derived from layer thickness (Svensson et al., 2008). Beyond $60 \mathrm{ka}$ BP we used constraints from the GICC05modelext timescale that was constructed by patching the ss09sea-modeled age scale shifted to younger ages by $705 \mathrm{yr}$ in order to match it to the end of the annual-layercounted timescale (Wolff et al., 2010). As for GICC05, the thinning function for the GICC05modelext was taken from the Dansgaard-Johnsen ice flow model adapted to NGRIP, whereas the accumulation rate of GICC05modelext beyond $60 \mathrm{ka} \mathrm{BP}$ was calculated from the water isotope data (NGRIP Members, 2004) in the absence of continuous layer counting over that core section.

\subsection{Vostok ice core record}

The GT4 timescale published by Petit et al. (1999) treated the whole length of the Vostok ice core corresponding to the last $400 \mathrm{ka} \mathrm{BP}$ and is based primarily on glaciological modelling with limited point anchoring to selected intervals of a marine $\delta^{18} \mathrm{O}$ and magnetic susceptibility records. More recently, Parrenin et al. $(2001,2004)$ improved the dating of the 
Vostok record through inverse dating methods by building an initial thinning function, taking into account the ice origin and a range of anchoring points $\left({ }^{10} \mathrm{Be}\right.$ alongside six orbital climatic links between insolation peaks and mid-slopes of $\delta \mathrm{D}$ at Termination I with a lag of $3000 \mathrm{yr}$ ). These orbital points were also included in the LD2010 timescale, but have been removed in the current AICC2012 chronology (Bazin et al., 2013), whereas the thinning scenario for Vostok initially proposed by Parrenin et al. (2004) has been retained in the AICC2012 background scenario (see SOM).

\subsection{EPICA Dome C (EDC) ice core record}

The EDC record covers the last $800 \mathrm{ka}$ BP (EPICA Community Members, 2004; Jouzel et al., 2007; Loulergue et al., 2008), and currently, analysis of this ice core relies on the EDC3 chronology proposed by Parrenin et al. (2007) based on ice flow modelling and an inverse method constrained by a limited number of reference age markers. Over the last Termination, the EDC3 age scale used two methane tie points for synchronization with the layer-counted Greenland GICC05 chronology. Other age markers include an absolutely dated ash layer (Dunbar et al., 2008), peaks in cosmogenic isotopes (Raisbeck et al., 2007), and a speleothem-derived absolute age link with the abrupt methane increase at Termination II, and only orbital tuning and a single absolute age marker (the Brunhes-Matuyama reversal recorded in ${ }^{10} \mathrm{Be}$ ) beyond (Parrenin et al., 2007). Recently, Parrenin et al. (2013) provided evidence of no-lag between atmospheric $\mathrm{CO}_{2}$ and surface air temperature during the last deglacial warming at EDC based on revised relative age scale for the EDC record. It has been constructed following improved depth synchronization between the EDC ice cores, improved $\delta^{15} \mathrm{~N}$-based $\Delta$ depth estimates in constraining the gas age, and linear interpolation between selected tie-points.

\subsection{EPICA Dronning Maud Land (EDML) ice core record}

The EPICA Dronning Maud Land EDML-1 timescale, covering the last $150 \mathrm{ka} \mathrm{BP}$, has been derived directly from the EDC3 timescale (Parrenin et al., 2007) by stratigraphic matching and data synchronization between the two ice records (Ruth et al., 2007). Over the last $128 \mathrm{ka} \mathrm{BP,} 322 \mathrm{com}-$ mon volcanic stratigraphic horizons were identified in both ice cores. Additional chronological control has been derived from dated volcanic events and the match to the GICC05 timescale via ${ }^{10} \mathrm{Be}$ and methane. The difference between EDML-1 and EDC3 was estimated as less than $450 \mathrm{yr}$ over the last $128 \mathrm{ka} \mathrm{BP}$, and lower than $130 \mathrm{yr}$ over the last $60 \mathrm{ka}$ BP (Ruth et al., 2007).

\subsection{Talos Dome (TALDICE) ice core record}

The TALDICE ice core record drilled at Talos Dome in East Antarctica covers the last $250 \mathrm{ka}$ BP (Stenni et al., 2011).
The TALDICE-1 chronology first published by Buiron et al. (2011) uses stratigraphic (ice and gas) markers to constrain the inverse modelling method of Lemieux-Dudon et al. (2010). This chronology is principally based on methane synchronizations (Spahni et al., 2005; Blunier et al., 2007; Loulergue et al., 2007) with Greenland composite and EDC records. Due to the high accumulation rates in the area, TALDICE provides decadal time resolution during the Holocene and the last deglaciation. The relative uncertainties reported were relatively small, $300 \mathrm{yr}$ for early Holocene and the last deglaciation, $500 \mathrm{yr}$ back to $17.5 \mathrm{ka} \mathrm{BP}$, and up to $1500 \mathrm{yr}$ for the last glacial, but increased significantly for older periods (Buiron et al., 2011).

A chronological refinement for the period $55-112 \mathrm{ka}$ BP and called TALDICE-1a has been proposed by Schüpbach et al. (2011) using high-resolution methane synchronization with the EDC methane record (Loulergue et al., 2007, 2008). Based on this approach, and employing several newly defined tie-points, the uncertainties relative to EDC3 were lowered to less than $1100 \mathrm{yr}$ for this interval.

\section{Methodology and approach}

\subsection{The Datice inverse modelling}

The probabilistic inverse modelling employed here is an updated version of the Datice Bayesian inference tool presented in Lemieux-Dudon et al. (2010). The model dynamically constructs parallel chronologies simultaneously for the analyzed ice core records by correcting the associated background information for past accumulation rates, thinning function, and lock-in-depth in ice equivalent (LIDIE), and taking into account independent stratigraphic markers for the ice (based on volcanogenic sulphate, tephra, and ${ }^{10} \mathrm{Be}$ data) and gas (derived from $\mathrm{CH}_{4}$ and $\delta^{18} \mathrm{O}_{\mathrm{atm}}$ ), as well as absolute and orbital age estimates. The optimization of this approach is therefore dependent also on the number, distribution and uncertainties associated with the tie-points (Buiron et al., 2011). The optimization of the system provides analyzed ice and gas chronologies for each ice core as well as modified glaciological quantities (i.e. thinning function, accumulation rate, and LIDIE, respectively).

A detailed description of the model and its application is provided in Lemieux-Dudon et al. (2010), and information on the current constraints and application updates are presented in more detail in the SOM and Bazin et al. (2013).

\subsection{Application}

\subsubsection{Background information}

A comprehensive presentation of the background parameters used (initial thinning, accumulation rate, and LID with the associated variances) is given in the SOM. For our application, one aim was to produce an Antarctic chronology that 
was tied to GICC05 over the last $60 \mathrm{ka} \mathrm{BP}$, and independent beyond. This decision enables straightforward comparisons between Greenland and Antarctica, without introducing a new Greenland age scale for the last $60 \mathrm{ka}$ BP that based on our observations would very closely follow GICC05. We consider this approach to be justified until significant and validated new absolute age markers in this age interval will be available. As a consequence, the background thinning and accumulation rate profiles for NGRIP are exactly those of GICC05 and GICC05modelext (Svensson et al., 2008; Wolff et al., 2010). For the Antarctic ice cores, the background thinning scenarios were deduced from glaciological models, whilst the accumulation rate was deduced from the water isotopes records through a simple exponential law (details in SOM). The associated variances were adjusted so that: (1) the final thinning function was allowed to deviate more from the background scenario for drilling sites with a complicated ice flow history (e.g. EDML (Huybrechts et al., 2007) and Vostok (Parrenin et al., 2001) on a dome flank; TALDICE (Stenni et al., 2011) with probably increased ice sheet thickness at the Last Glacial Maximum); and (2) the final accumulation rates were allowed to deviate more from the background scenarios when output values deviated far from present-day values based on which the exponential law linking accumulation rate and water isotopes had been calibrated (details in SOM).

Finally, where modelling outputs agreed with constraints from the $\delta^{15} \mathrm{~N}$-based estimates, the background LIDIE was calculated from firn densification models such as for TALDICE (Capron et al., 2013) or NGRIP (Landais et al., 2004; Huber et al., 2006). At the other sites, a background scenario derived from $\delta^{15} \mathrm{~N}$ was chosen, since it gives more plausible results over the last deglaciation, as for example at EDC (Parrenin et al., 2012b, 2013). This choice of LIDIE background scenario is important since in remote sites of East Antarctica such as Vostok and EDC, the LIDIE is almost $65 \%$ smaller for the glacial period when using the $\delta^{15} \mathrm{~N}$ scenario, assuming no increase of convective zone (during glacial period) compared to the outputs derived from classical firn densification modelling (Schwander et al., 1997; Arnaud et al., 2000; Goujon et al., 2003). Moreover, because there are still questions of what is the best background LIDIE to choose between densification modelling and $\delta^{15} \mathrm{~N}$, larger variances for LIDIE have been associated for the latter sites, where model and $\delta^{15} \mathrm{~N}$-derived constraints strongly disagree (see SOM). Finally, both LIDIE scenarios have been tested (SOM), and although none of the LIDIE background scenarios is fully satisfying, it confirms the results of Parrenin et al. (2012b, 2013) that over the last deglaciation at EDC, the LIDIE calculated from $\delta^{15} \mathrm{~N}$ is in much better agreement with the combination of ice and gas stratigraphic markers than the LIDIE calculated by firn densification models alone.

\subsubsection{Ice stratigraphic markers}

Recently, Parrenin et al. (2012a) refined and extended the synchronization between EDC and Vostok ice cores over the interval 0-145 ka BP through the identification of common volcanic sulphate stratigraphic marker horizons. One hundred four (104) volcanic tie links were proposed following on the previous work of Udisti et al. (2004) that covered only the 0-45 ka BP interval. The synchronization-related uncertainties included in our study were grouped into three ranges, $200 \mathrm{yr}$ for the last $40 \mathrm{ka} \mathrm{BP}, 150-350 \mathrm{yr}$ between $105-145 \mathrm{ka}$ $\mathrm{BP}$ and $500 \mathrm{yr}$ for the glacial period. The relatively large uncertainty reflects the fact that volcanic tie-points are not retrieved from a single core at Vostok but from a combination of ice cores with possible shifts of up to $3 \mathrm{~m}$ in-between the individually logged core depths (Parrenin et al., 2012a).

The EDC and EDML ice core records were also synchronized, using mainly volcanic stratigraphic markers identified in the ice phase (Ruth et al., 2007; Severi et al., 2007). We translated the original EDC96 core depths on which these markers were first proposed to the corresponding depths of core EDC99 (following the approach of Parrenin et al., 2012a), and include in our analysis 273 stratigraphic tie links derived from these two records. The majority of the tie points cover the last $120 \mathrm{ka}$ (Fig. 1). Uncertainties attached to these points were $20 \mathrm{yr}$ for "certain" tie points and $100 \mathrm{yr}$ for "probable" tie-points, depending on the proposed confidence levels and our revision (Ruth et al., 2007; Severi et al., 2007).

The work by Severi et al. (2012) reports on the recently accomplished age scale synchronization between the TALDICE and the EDC ice cores, and carried on through the identification of common glaciochemical volcanic signatures. From the range of markers proposed, we employed in our analysis 112 markers (only the "certain" and "probable" ones) stretching over the last $42 \mathrm{ka} \mathrm{BP}$, with attached uncertainties of 20 and $100 \mathrm{yr}$. Prior to the analysis, the original EDC96 core depths on which these markers were first proposed were translated to the depths of core EDC99 (Fig. 1). Moreover, two stratigraphic tie links with uncertainties of $110 \mathrm{yr}$ tie the EDC and the NGRIP records at the Laschamp geomagnetic excursion (Loulergue et al., 2007).

New records of bipolar volcanic spikes matching between EDML and NGRIP ice cores are currently being proposed following the identification of common glaciochemical stratigraphic features in both records for the Holocene (Vinther et al., 2012), and around $41 \mathrm{ka} \mathrm{BP}$, at the time of the Laschamp geomagnetic excursion (Svensson et al., 2013). The EDML - NGRIP synchronization is further constrained by annual layer counting between the tie points, resulting in a strong interhemispheric link at decadal precision between GI-20 and AIM19/20 at the time of the Toba eruption, around $74 \mathrm{ka} \mathrm{BP}$. From the data points proposed, we used 87 tie links with $50 \mathrm{yr}$ uncertainties for the Holocene and MIS 3, and 100 yr uncertainty for those identified in late MIS 5 (Fig. 1). 


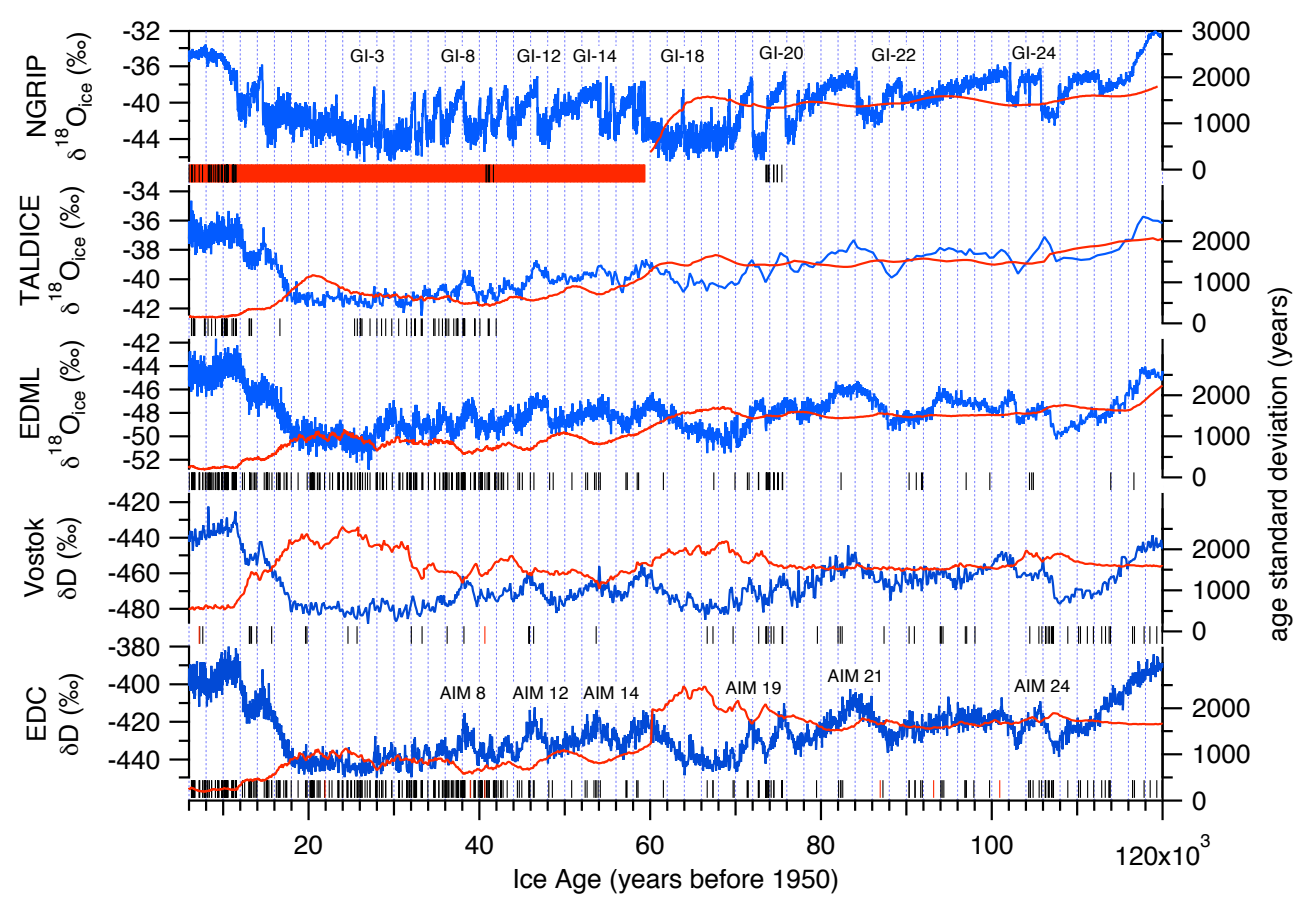

Fig. 1. Water isotopic records from the five ice cores analyzed. From top to bottom: NGRIP (NGRIP members, 2004), TALDICE (Stenni et al., 2011), EDML (EPICA Community Members, 2006), Vostok (Petit et al., 1999), and EDC (Jouzel et al., 2007) on the AICC2012 chronology. Vertical black bars indicate the location of the ice stratigraphic markers and red bars the location of the absolute tie-points in the ice phase. For NGRIP, absolute tie-points are located every meter to closely fit AICC2012 chronology to GICC05 over the last 60 ka. The red lines (right axes) show the ice age standard deviation in years for each of the ice core analyzed. GI- refers to Greenland interstadials and the AIM to selected Antarctic Isotopic Maxima events.

No volcanic stratigraphic ice tie points have been reported between Vostok and EDML, TALDICE or NGRIP, or between TALDICE and EDML.

\subsubsection{Gas stratigraphic markers}

Methane and the isotopic composition of oxygen $\left(\delta^{18} \mathrm{O}_{\mathrm{atm}}\right)$ from air bubbles entrapped in ice provide exceptional tools for synchronizing ice core records (Bender et al., 1994; Blunier et al., 1998; Capron et al., 2010; Köhler, 2010). With a decadal resolution in some ice records, methane shows variations strongly linked to rapid climatic fluctuations such as the centennial-to-millennial climate variability (Chappellaz et al., 1993; Mitchell et al., 2011). The same pattern of change is recorded by both $\mathrm{CH}_{4}$ and $\delta^{18} \mathrm{O}_{\text {atm }}$ in Greenland or Antarctic ice core records, even though $\delta^{18} \mathrm{O}_{\text {atm }}$, driven by precession as well as millennial-scale climate events, shows lower amplitude variations because of the longer $\mathrm{O}_{2}$ lifetime (Landais et al., 2010).

The gas stratigraphic links employed were derived primarily from literature following established inter-core methane synchronizations, but also from the available $\delta^{18} \mathrm{O}_{\mathrm{atm}}$ data. Additionally, the $\delta^{15} \mathrm{~N}$ data are also used as markers of rapid warming in the NGRIP ice core record in sections where methane constraints are not yet available (Capron et al., 2010). More specifically, the methane gas stratigraphic links are derived from the synchronizations performed between EDC and the records of Vostok (Loulergue, 2007; Lemieux-Dudon et al., 2010), EDML (Loulergue, 2007; Loulergue et al., 2007; Schilt et al., 2010), TALDICE (Buiron et al., 2011; Schüpbach et al., 2011; Parrenin et al., 2012b), or NGRIP (Greenland composite: Capron et al., 2010; EPICA Community Members, 2006; Flückiger et al., 2004; Huber et al., 2006; Schilt et al., 2010), respectively. NGRIP is another ice core record that has already been synchronized in the gas phase to all other records analyzed here including Vostok (Landais et al., 2006), EDML (Capron et al., 2010; Lemieux-Dudon et al., 2010; Schilt et al., 2010), or more recently TALDICE (Buiron et al., 2011). Other available gas stratigraphic pairing includes only these between EDML and TALDICE with data derived from Schüpbach et al. (2011) (details in SOM).

\subsubsection{Absolute age markers}

The imprint of the Laschamp geomagnetic excursion has been detected in the ice cores based on ${ }^{10} \mathrm{Be}$ concentration trends in both Greenland (Yiou et al., 1997) and Antarctic (Raisbeck et al., 2007) records. We use the latest age constraints associated with this event, $40.65 \pm 0.95 \mathrm{ka}$ (Singer et 


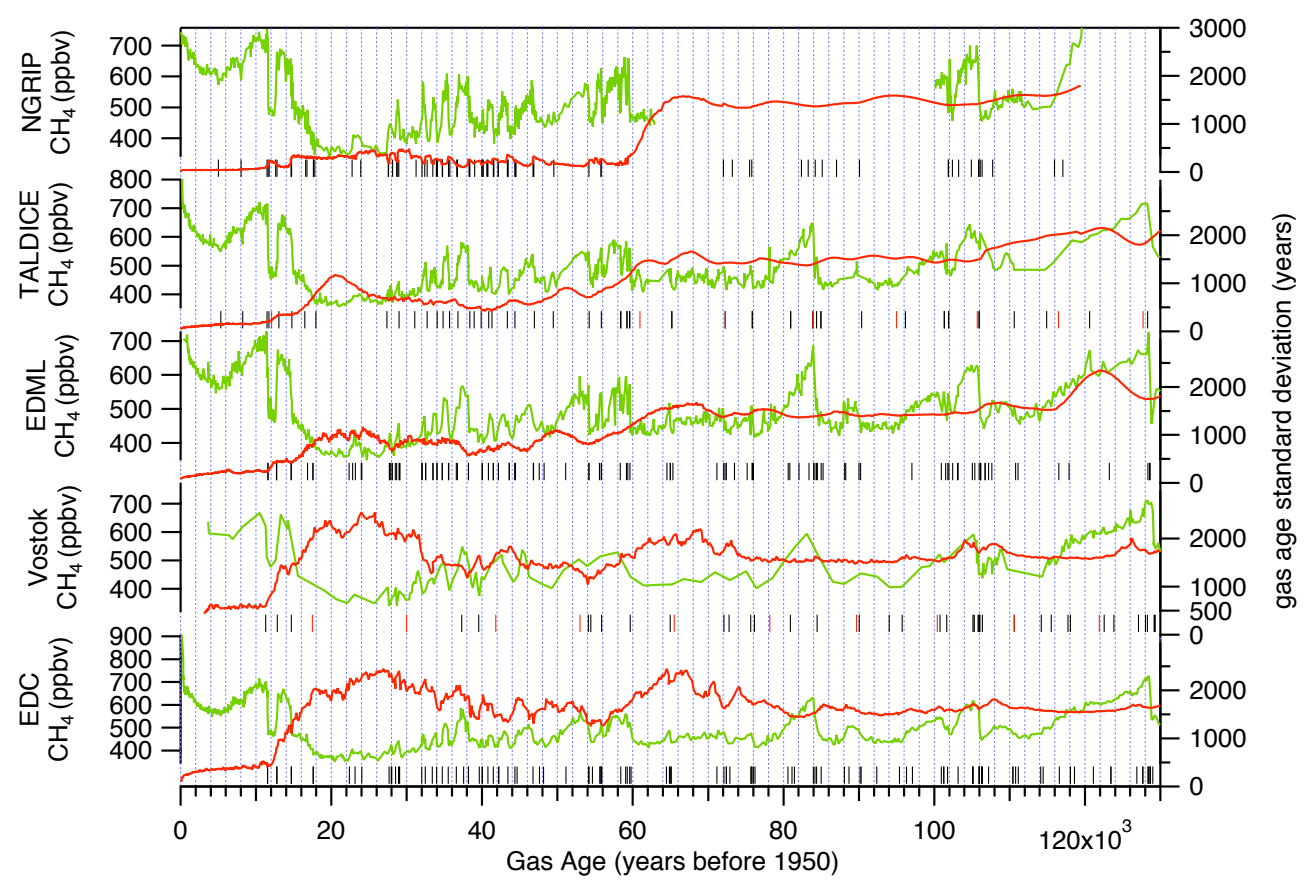

Fig. 2. The methane records of the five ice cores analyzed. From top to bottom: NGRIP (Greenland composite: Flückiger et al., 2004; Huber et al., 2006; EPICA Community Members, 2006; Schilt et al., 2010; Capron et al., 2010), TALDICE (Buiron et al., 2011; Schüpbach et al., 2011), EDML (EPICA Community Members, 2006), Vostok (Caillon et al., 2003; Petit et al., 2009) and EDC (Loulergue et al., 2008) on the AICC2012 gas chronology. Vertical black bars indicate the location of the gas stratigraphic markers and red bars the location of the absolute tie points in the gas phase. The red lines (right axes) show the gas age standard deviation in years for each of the ice core analyzed.

al., 2009) as absolute tie points for EDC and Vostok. Other absolute markers include a Holocene ${ }^{10} \mathrm{Be}$ point for Vostok (Parrenin et al., 2001) and the Mount Moulton tephra layer (Narcisi et al., 2006; Dunbar et al., 2008) for EDC, the latter with an updated ${ }^{40} \mathrm{Ar} /{ }^{39} \mathrm{Ar}$ age of $93.2 \pm 4.4 \mathrm{ka}$ (see SOM). Absolute age markers have not yet been reported for EDML and TALDICE records. For the NGRIP on the other hand, we used a set of absolute markers from the GICC05 depth-age relationship with artificially small uncertainties to force the model not to deviate from this chronology. Tie points spaced $60 \mathrm{yr}$ apart were used, leading to 990 data points to which we associated uncertainties of maximum $50 \mathrm{yr}$ rather than the reported GICC05 maximum counting errors. In return, the absolute gas age markers employed in LD2010 were not used for this work. For periods older than $120 \mathrm{ka}$ BP, the choice of absolute tie points for all records is discussed in Bazin et al. (2013).

\subsubsection{Additional markers}

The $\Delta$ depth markers given for NGRIP are derived from a depth comparison between $\delta^{18} \mathrm{O}_{\text {ice }}$ and air $\delta^{15} \mathrm{~N}$ over a succession of interstadials as detailed in the SOM. The new orbital points are discussed in Bazin et al. (2013).

\section{Results and discussion}

\subsection{The new AICC2012 gas and ice chronologies}

As expected from the chronological constraints provided by the numerous gas stratigraphic markers employed, the methane records for all five ice cores display very similar variations over the rapid millennial variability of the last glacial period and last deglaciation, respectively (Fig. 2). The uncertainties attached to the gas and ice stratigraphic tie points as well as uncertainties in the analyzed LIDIE may lead locally to some minor offsets up to a few centuries between the five methane records. In addition, small differences between the records could also reflect a combination of (1) different analytical resolution (e.g. the low resolution in the Vostok record) and precision, (2) the existence of the interhemispheric methane gradient because of possibly stronger proximal methane sources from Northern Hemisphere landmasses (Dällenbach et al., 2000; Schüpbach et al., 2011), and (3) different speeds for the lock-in process that could modulate the trace gases' peak attenuation observed in low accumulation sites (Spahni et al., 2003; Köhler, 2010).

At first order, the water isotopic profiles show consistent similarity between all Antarctic sites, despite the fact that none of the ice stratigraphic tie points are derived from water isotopic data (Fig. 1). This confirms that the AIM succession observed individually on the different Antarctic ice cores 


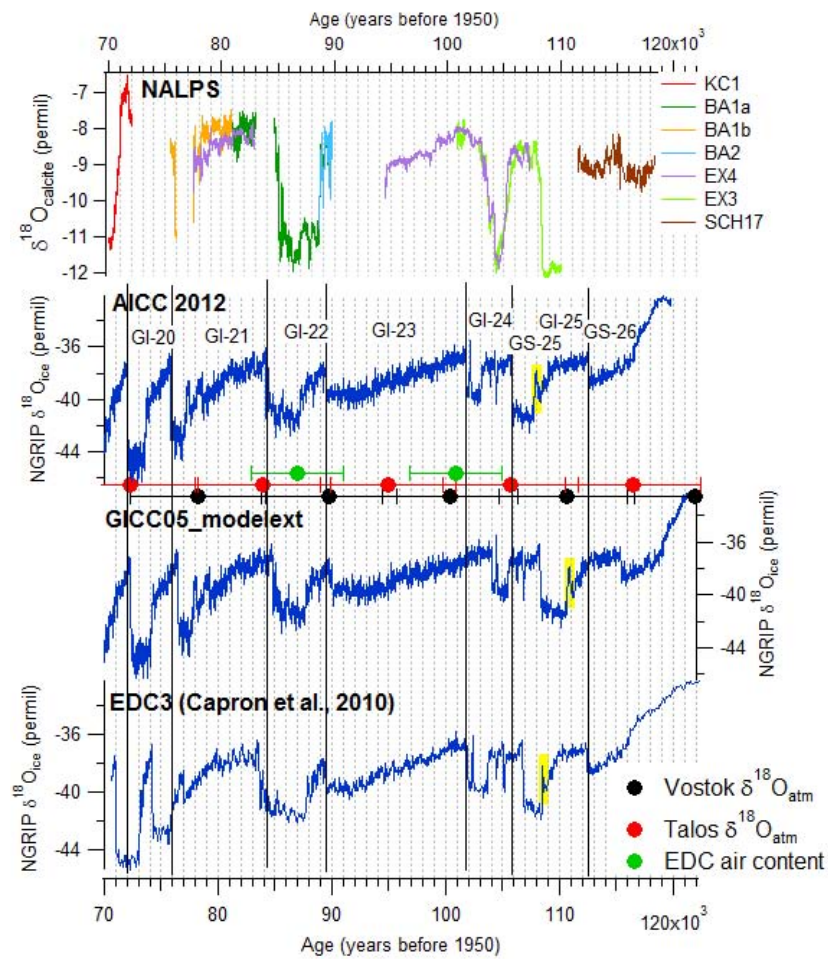

Fig. 3. Comparison of the NGRIP $\delta^{18} \mathrm{O}_{\text {ice }}$ evolution over the glacial inception on three different time series in use; top panel: AICC2012 (this work); middle panel: GICC05modelext (Wolff et al., 2010); bottom panel: EDC3 (Capron et al., 2010). The yellow highlight shows the location of the rebound event at the end of GI-25. The grey, vertical lines mark the major GS/GI transitions. The circles mark the orbital points with associated error bars $\left(\delta^{18} \mathrm{O}_{\text {atm }}\right.$ Vostok in black; $\delta^{18} \mathrm{O}_{\text {atm }}$ TALDICE in red; air content EDC in green). Note that the $\delta^{18} \mathrm{O}_{\text {atm }}$ orbital points were taken at mid-slopes for TALDICE (Bazin et al., 2013) and at minima and maxima for Vostok (Suwa and Bender, 2008). The speleothem color-coded composite NALPS $\delta^{18} \mathrm{O}_{\text {calcite }}$ record (Boch et al., 2011) is also shown for comparison.

(EPICA Community Members, 2006; Jouzel et al., 2007; Wolff et al., 2009; Buiron et al., 2012) is a persistent feature of the Antarctic climate of the last glacial period, even if some differences are clearly visible on the shapes of the AIM for the different ice core records (Fig. 1). The EDML water isotope record shows AIM characterized by broader peaks or even extended periods of high isotope values, whereas the EDC and TALDICE exhibit a more triangular shape over the same AIM events. The temperature maximum over each AIM is thus reached earlier at EDML compared to EDC (see Fig. 4), potentially reflecting that the EDML area picks up a South Atlantic temperature signal that is opposite to the North Atlantic signal, and that according to the bipolar seesaw theory would be expected to increase more rapidly than Antarctic temperatures (Stocker and Johnsen, 2003). The water isotopic record is often of too coarse a resolution in Vostok to clearly see the shape of the AIM.

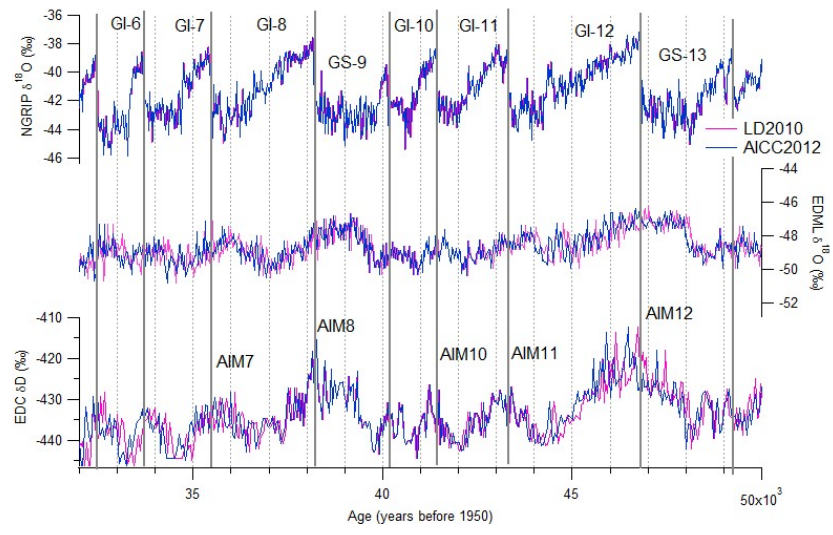

Fig. 4. Water isotopic records of NGRIP (top), EDML (middle), and EDC (bottom), over GI-5 to 12 on the LD2010 timescale in pink, versus the new AICC2012 chronology using additional constraints (this study) in blue. For comparison on the timing of events, the black vertical lines mark the major GS/GI transitions in the NGRIP record.

Within the new coherent chronological scenario, we have chosen to briefly discuss two aspects for the last glacial cycle: first, the dating of the last glacial inception in Greenland; second, the implication for the bipolar sequences of events and the seesaw picture over middle MIS 3.

\subsection{Comparison with previous chronological constraints in the 70-120 ka BP period as derived from EDC3 and GICC05modelext}

By construction, the AICC2012 chronology closely follows the GICC05 timescale over the last $60 \mathrm{ka}$ with a maximum difference of $5 \mathrm{yr}$ locally. This is due to the high number of absolute ice markers with artificially small uncertainties included for this period, derived from the GICC05 chronology (Fig. 1). For older periods such as MIS 5, a compromise had to be found between data constraints and initial input from glaciological modelling (SOM). Because the initial background scenario for the thinning function for Vostok, EDML, and TALDICE records was associated with quite a large variance over MIS 5, the AICC2012 is mainly constrained by a few orbital markers such as $\delta^{18} \mathrm{O}_{\text {atm }}$ and air content with large uncertainties of $6000 \mathrm{yr}$ and respectively $4000 \mathrm{yr}$, and the background age model for EDC (Parrenin et al., 2007) and NGRIP (Wolff et al., 2010) ice cores (see also Bazin et al., 2013).

In Fig. 3 the water isotopic record of NGRIP over the glacial inception and late MIS 5 presented on the AICC2012 chronology is compared with the same record on both the GICC05modelext and EDC3-based timescales, as discussed in Capron et al. (2010). In that study, the EDC3-based chronology was applied to the NGRIP record by using gas stratigraphic links $\left(\mathrm{CH}_{4}\right.$ and $\left.\delta^{18} \mathrm{O}_{\mathrm{atm}}\right)$ between the EDML and NGRIP ice core records, the EDML record being drawn 


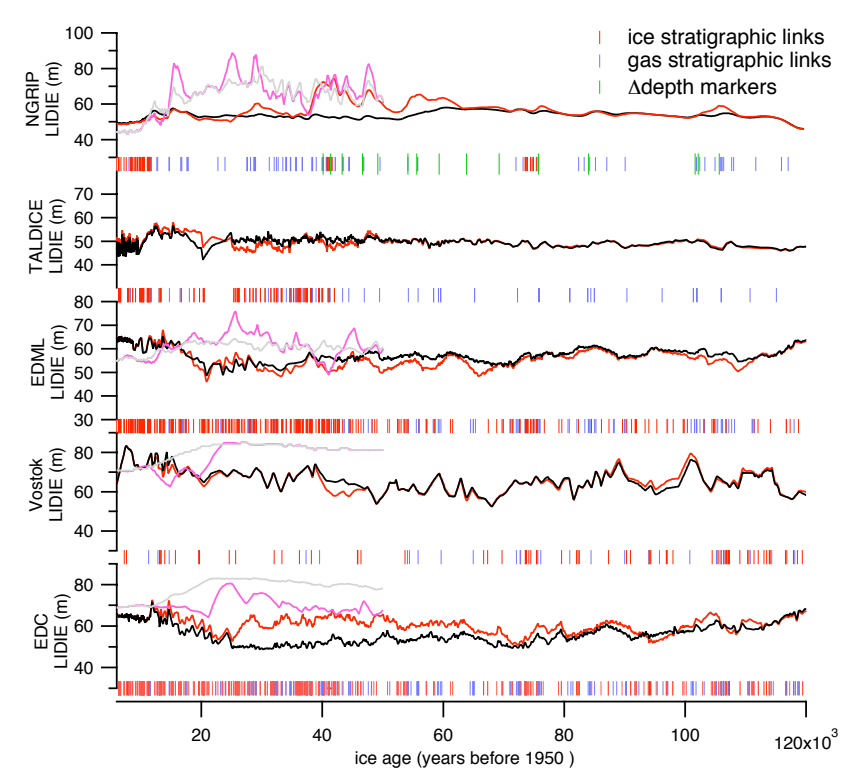

Fig. 5. Evolution of the LIDIE over the last $120 \mathrm{ka}$ for the five ice core records analyzed in this study: background LIDIE scenarios for the LD2010 (grey) and the AICC2012 chronologies (black); Daticecalculated LIDIE for the LD2010 (pink) and the AICC2012 (red) chronologies. The blue, red, and green vertical bars mark the location of ice stratigraphic links, gas stratigraphic links, and $\Delta$ depth markers, respectively.

on the EDML-1 timescale (Ruth et al., 2007) initially tuned to the EDC3 chronology (Parrenin et al., 2007) through many volcanic tie points.

Significant differences of several millennia are observed in the timing of the NGRIP glacial inception record between the AICC2012, the GICC05modelext, and the EDC3 chronologies (Fig. 3). The timing of the onsets of GI-25, GI-23, and GI-22 are comparable between the EDC3-based and AICC2012 timescales, but younger than the onset of the same interstadial according to the GICC05modelext. In our view, this difference is likely due to the high uncertainty on the NGRIP thinning function in sectors near the bedrock (NGRIP members, 2004; Wolff et al., 2010), but also because it is mainly the EDC background scenario and the few orbital points (Fig. 3) that are driving the AICC2012 chronology over the interval $85-120 \mathrm{ka}$ BP. The constraint linked to the orbital points is especially important around $100 \mathrm{ka} \mathrm{BP}$, which makes the timing of GI-24 in AICC2012 younger than both GICC05modelext and EDC3 (by $\sim 2500$ and $\sim 1000 \mathrm{yr}$, respectively). For the period $60-85 \mathrm{ka} \mathrm{BP}$, the AICC2012 chronology provides a compromise between EDC3 and GICC05modelext with for example the onsets of GI-21 and GI-20 being dated in AICC2012 at intermediate ages between these of corresponding events on the EDC 3 and GICC05modelext timescales (Fig. 3).

The duration of events has been strongly modified for the NGRIP $\delta^{18} \mathrm{O}_{\text {ice }}$ record between the EDC3-based and the
AICC2012 chronology. Especially the duration of the $\delta^{18} \mathrm{O}_{\text {ice }}$ decrease from the climatic optimum of MIS 5.5 and GS-26 is similarly shorter on the GICC05modelext and AICC2012 timescales compared to the EDC3-based chronology (Fig. 3). In addition, the rebound event at the end of GI-25 (yellow hatch on Fig. 3) is much shorter on the EDC3-based chronology of Capron et al. (2010) but has similar duration according to AICC2012 and GICC05modelext.

Table 1 shows a comparison on the duration of selected Greenlandic climate events as constrained by AICC2012, the GICC05modelext (Wolff et al., 2010), and the EDC3based NGRIP timescale of Capron et al. (2010). As mentioned above, the event durations calculated from AICC2012 are in better agreement with GICC05modelext than with the EDC3-based timescale (Table 1). This is expected from the fact that both GICC05modelext and AICC2012 chronologies use glaciological information, i.e. the glaciological kink model for GICC05modelext (Wolff et al., 2010), and a combination of this same NGRIP kink model with the EDC glaciological model of Parrenin et al. (2007) for the AICC2012 chronology. Still, some differences remain between the AICC2012 and the GICC05modelext chronologies (Fig. 3), as is for example the case for the duration of events GI-20, GS-22, GI-24, or GS-25 (Table 1). Moreover, the DATICE tool has been developed to provide robust uncertainty on the absolute age but not yet for the duration of events. Still, a development is ongoing in integrating the uncertainty on event duration from layer counting information; this methodological update will be provided in a future submission (Lemieux-Dudon et al., 2013).

\subsection{Comparison with NALPS in the 70-120 ka BP period}

U/Th absolutely dated speleothem isotopic data provide valuable contributions for better constraining the uncertainties associated with ice core dating and assessing leads and lags in the regional response to past climate change (Drysdale et al., 2007; Wang et al., 2008; Cheng et al., 2009; Fleitmann et al., 2009). Although detailed comparison between AICC2012 and other independent and absolutely dated archives will be attempted in the near future (see also discussion in SOM), we briefly compare the AICC2012 chronological constraints over the last glacial inception with the recently published NALPS record (Boch et al., 2011).

The NALPS composite speleothem record extends between 120 and $60 \mathrm{ka} \mathrm{BP}$ and provides a precisely dated cave paleoclimate time series from the northern Alpine region. The observed calcite $\delta^{18} \mathrm{O}$ variations were interpreted to reflect the North Atlantic type climate variability (Boch et al., 2011). There is good agreement for the timing of GI/GS events 19 to 25 between NALPS and GICC05modelext, but differences such as younger ages for speleothem stadial and interstadial transitions over the period between ca. 106 and $60 \mathrm{ka}$ have also been reported. However, as NALPS is 
Table 1. Overview of event durations over the period 70-120 ka BP of the NGRIP $\delta^{18} \mathrm{O}_{\text {ice }}$ as constrained on three different ice core time series: AICC2012 (this study), GICC05modelext (Wolff et al., 2010) and the EDC-3 (Capron et al., 2010), and the NALPS composite speleothem record (Boch et al., 2011). Stadial-interstadial boundaries have been defined by eye using $20 \mathrm{yr}-$ resolution $\delta^{18} \mathrm{O}$ data and $\mathrm{Ca}^{2+}$ data from the NGRIP, GRIP, and GISP2 ice cores synchronized to GICC05 following the method described in Rasmussen et al. (2008). The details of this approach will be reported elsewhere (I. Seierstad, personal communication, 2012). The short events within GS-24 and GS-22 ("precursor events") are not included in the GI and GS duration estimates, and the definition of GS-22 follows Vallelonga et al. (2012). As there is no clear evidence of GS-23 in Greenland water isotopic records we give the duration of GI-23 and GS-23 as a whole.

\begin{tabular}{ccccc}
\hline Event & \multicolumn{4}{c}{ Duration of events (years) } \\
\hline & AICC2012 & $\begin{array}{c}\text { GICC05modeltext } \\
\text { (Wolff et al., 2010) }\end{array}$ & $\begin{array}{c}\text { EDC3 } \\
\text { (Capron et al., 2010) }\end{array}$ & $\begin{array}{c}\text { NALPS } \\
\text { (Boch et al., 2011) }\end{array}$ \\
\hline GI-20 & 2166 & 2340 & 1067 & \\
GI-21 & 1340 & 1320 & 1716 & $1720 \pm 384$ \\
GI-21 & 7009 & 7000 & 7731 & $7450 \pm 475$ \\
GI-22 & 2760 & 2620 & 3625 & $3250 \pm 526$ \\
GI-22 & 2467 & 2440 & 1839 & \\
GS-23+GI-23 & 12512 & 14000 & 12940 & $1040 \pm 585$ \\
GI-24 & 950 & 920 & 1220 & $3090 \pm 636$ \\
GI-24 & 2650 & 2840 & 3140 & \\
GI-25 & 1990 & 2360 & 1700 & \\
GI-25 & 4790 & 4730 & 3900 & \\
\hline
\end{tabular}

compiled from several stalagmites that have been affected by growth cessation particularly during stadials, the record is highly discontinuous, and not all DO event boundaries could securely be identified.

The timing of events over the period $70-85 \mathrm{ka}$ is well constrained between AICC2012 and NALPS, particularly for the onsets of GI-19 and GI-20 (Fig. 3). The onset of GI-21 is however around $500 \mathrm{yr}$ younger in AICC2012, and the discrepancy already reported between NALPS and GICC05modelext over the length of GS-22 is also visible in AICC2012. It is likely the cause of this discrepancy resides in the NALPS record, or arises from different expressions of climate variability in the different records.

A significant offset is, however, observed over the early part of the Last Glacial period between NALPS and AICC2012, the speleothem-derived event boundaries being older by $\sim 2000 \mathrm{yr}$ on average compared to AICC2012 over the sequence of GI/GS events 23-25. Over the same interval there is however better agreement between NALPS and GICC05modelext (Fig. 3). Nonetheless, differences exist in the timing and shape of events over GI/GS events $24-25$ between NALPS and other well-dated speleothem records such as Corchia, south of the Alps (Drysdale et al., 2007), Sofular, near the Black Sea (Badertscher et al., 2011), or the Sanbao record from China (Wang et al., 2008). A rigorous chronological analysis of various speleothem records is underway (D. Fleitmann, personal communication, 2012). It is expected that it will provide strong constraints for further comparison of such records with the ice core chronological data, including AICC2012. As for the length of events, the error bars associated with the NALPS record make it compatible, at least for some events, with any of the ice core chronologies discussed in Fig. 3.

\subsection{Middle MIS 3 - comparison with the LD2010 chronology}

One of the strengths of the Datice tool is that it allows for a close assessment of the sequence of events between the different ice cores analyzed. This is particularly relevant for the new AICC2012 chronology that is more carefully constrained with the addition of numerous new gas and ice stratigraphic links between the various ice cores (Figs. 1 and 2). Since we analyzed both Greenland and Antarctic records, the outcome has immediate implications for the timing of the interhemispheric coupling over the last glacial period with respect to the seesaw mechanism (Stocker and Johnsen, 2003; EPICA Community Members, 2006; Barker et al., 2011; Buiron et al., 2012).

A central period for investigating the classical bipolar expression of the millennial variability over the last glacial period is MIS 3 (Blunier and Brook, 2001; EPICA Community Members, 2006; Jouzel et al., 2007; Wolff et al., 2010). With the AICC2012 chronology, the classical pattern where the peaks of AIM correspond with the GI onsets is indeed confirmed (Fig. 4), as already reported in the previous Daticederived LD2010 chronology (Lemieux-Dudon et al., 2010).

Nevertheless, slight differences were expected between the two chronological frameworks given the improved constraints applied here compared to LD2010. For example, for AIM5, 6, 7 and 12, the AICC2012 age estimates for the Antarctic records are younger by $\sim 500-600 \mathrm{yr}$ compared 
to the LD2010 chronology (Fig. 4). However, the slight differences in the AIM timing between the two Datice-derived chronologies do not impact significantly on the understanding of the sequence of events over the last glacial period between Antarctica and Greenland and hence on the seesaw mechanism. As an example, over GS-13/GI-12 there is a very good synchrony between the abrupt increase of $\delta^{18} \mathrm{O}_{\text {ice }}$ at NGRIP and the $\delta^{18} \mathrm{O}_{\text {ice }}$ maximum at EDC on the AICC2012 chronology. Using the LD2010 chronology, the isotopic maximum at EDC is lagging the abrupt increase of $\delta^{18} \mathrm{O}_{\text {ice }}$ at NGRIP by several centuries. Similarly, EDML displays generally younger $\delta^{18} \mathrm{O}_{\text {ice }}$ maximum over AIM by several centuries in AICC2012 than in LD2010 (Fig. 4).

Despite these small differences, the sequence of events remains in agreement with the seesaw classical pattern (Stocker and Johnsen, 2003; Svensson et al., 2013) within the limitations given by dating as well as the short-term variability of the water isotopic signal and related uncertainties derived from the temporal and analytical constraints employed (see SOM). For example, over the interval corresponding to the onset of GI- 8 at EDML, the maximum $\delta^{18} \mathrm{O}_{\text {ice }}$ at the beginning of the plateau is reached at least $1000 \mathrm{yr}$ - hence significantly more than the $600 \mathrm{yr}$ uncertainty - prior to the abrupt stadial-interstadial transition seen in Greenland. At EDC, for the same event, the maximum of the AIM is synchronous within the $600 \mathrm{yr}$ AICC2012 uncertainty with the abrupt stadial-interstadial transition recorded in Greenland, both for LD2010 and AICC2012.

For GS-13/GI-12, the maximum of $\delta^{18} \mathrm{O}_{\text {ice }}$ at EDML is reached $1000-1400 \mathrm{yr}$ before the abrupt warming recorded in Greenland, which is significantly larger than the $600 \mathrm{yr}$ AICC2012 uncertainty over this period and the difference between the LD2010 and AICC2012 chronologies. On the opposite, the maximum of $\delta^{18} \mathrm{O}_{\text {ice }}$ at EDC over AIM12 is synchronous within the AICC2012 uncertainty (i.e. $\pm 600 \mathrm{yr}$ ) with the Greenland abrupt warming.

The clear decrease of EDC and EDML $\delta^{18} \mathrm{O}_{\text {ice }}$ reflecting the Antarctic temperature occurs in-phase within dating uncertainties with the Greenland GS/GI transitions as depicted by the bipolar seesaw hypothesis. The EDML warming rate appears however much faster than the EDC warming rate which strengthen the hypothesis of a shorter response time of the Atlantic sector to an Atlantic Meridional Overturning Circulation weakening in the seesaw pattern (EPICA Community Members, 2006; Stenni et al., 2010; Buiron et al., 2012).

The fact that the Antarctic ice records are systematically younger during glacial periods according to the AICC2012 chronology than the LD2010 chronology is due to the different LIDIE scenarios (Fig. 5). The different LIDIE used for LD2010 relative to the AICC2012 are due to higher density of ice and gas stratigraphic points employed in the latter, as well as differences between the background LIDIE scenarios (SOM). Altogether, this approach had important implications for improving the accuracy of the new timescale.
For example, the LD2010 LIDIE background scenarios were all based on firn densification models. On the contrary, for AICC2012 the background LIDIE for EDML, EDC, and Vostok ice core records were deduced from the $\delta^{15} \mathrm{~N}$ of $\mathrm{N}_{2}$ in air entrapped in the ice (see Parrenin et al., 2012b; Capron et al., 2013). With this approach, LIDIE are systematically smaller in AICC2012 than in LD2010 (Fig. 5). The main implication is that a smaller LIDIE induces a smaller age difference, $\Delta$ age, between age of the ice and age of the gas at the same depth. It thus decreases the age of ice when using gas stratigraphic links as $\mathrm{CH}_{4}$ abruptly increases at each GS/GI transition.

\section{Conclusions and outlook}

Significant progress has been made recently in synchronizing the long ice core records, and this is an important benchmark in advancing paleoenvironmental research and more carefully assessing both temporal and spatial leads and lags between regions. Here we provided new chronological outputs from a multi-core inverse modelling approach applied to the more recent $120 \mathrm{ka}$ of four Antarctic ice core records, and the NGRIP record, in the frame of the AICC2012 chronology. The development of the new chronology to depict the millennial scale variability of the last glacial period has strongly benefited from the addition of numerous ice and gas stratigraphic tie points as well as a revised expression for the background scenario of LIDIE.

The new AICC2012 chronology provides improved temporal constraints in order to assess the timing of past climate events, and we have shown two such examples in selected time intervals over the last $120 \mathrm{ka}$ BP. First, the dating of the last glacial inception shares many features with the EDC3 chronology developed for the EDC record, but the implementation of new glaciological constraints (revised thinning and accumulation rate) make the duration of events in AICC2012 more reliable than previous estimates. Second, we have shown that the bipolar sequence of events over the succession of GI/GS is slightly modified in AICC2012 compared to the previous LD2010 chronology, with the Antarctic records in general being about $600 \mathrm{yr}$ younger according to the AICC2012.

Several other well-resolved Antarctic ice core records are available for the last climatic cycle and even beyond, with a wealth of dating information including layer counting (Mitchell et al., 2012; Vinther et al., 2012) or orbital markers (Kawamura et al., 2007). Moreover, radiometric age data from well-resolved speleothem profiles could provide absolute chronostratigraphic tie points that can refine the ice core chronologies, providing that the response to climate forcing is proven coeval between regions. It is therefore expected that the future contribution of both other ice cores and other types of chronological constraints to the Datice effort will lead to 
further refinements in the ice core chronologies beyond the AICC2012 chronology.

\section{Supplementary material related to this article is available online at: http://www.clim-past.net/9/1733/ 2013/cp-9-1733-2013-supplement.zip.}

Acknowledgements. The authors thank the EDC4 discussion team for stimulating the discussion around the building of AICC2012 and helping to decide on the best parameters to feed the DATICE tool. We are particularly indebted to V. Masson-Delmotte, C. Ritz, H. Fisher, and D. Fleitmann for their constructive suggestions. We further thank the anonymous reviewers and handling editor E. Brook for the critical reviews that improved the manuscript.

This work was financially endorsed mainly by LGGE the CNRS/INSU LEFE program and "Fondation Ars Cuttoli". The research leading to these results has also received funding from the European Union's Seventh Framework programme (FP7/20072013) under grant agreement no 243908, "Past4Future. Climate change - Learning from the past climate" and is Past4Future contribution number 47 . This is also TALDICE publication no 35 . This work is also a contribution to the European Project for Ice Coring in Antarctica (EPICA), a joint European Science Foundation/European Commission scientific programme, funded by the EU and by national contributions from Belgium, Denmark, France, Germany, Italy, the Netherlands, Norway, Sweden, Switzerland and the United Kingdom. The main logistic support was provided by IPEV and PNRA (at Dome C) and AWI (at Dronning Maud Land). This is EPICA publication no. 293.

Edited by: E. Brook

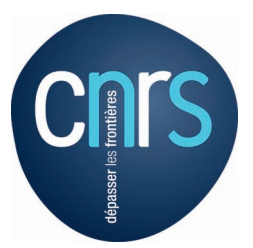

The publication of this article is financed by CNRS-INSU.

\section{References}

Arnaud, L., Barnola, J.-M., and Duval, P.: Physical modeling of the densification of snow/firn and ice in the upper part of polar ice sheets, in: Physics of Ice Core Records, edited by: Hondoh, T., Hokkaido University Press, Sapporo, Japan, 285-305, 2000.

Badertscher, S., Fleitmann, D., Cheng, H., Edwards, R. L., Göktürk, O. M., Zumbühl, A., Leuenberger, M., and Tüysüz, O.: Pleistocene water intrusions from the Mediterranean and Caspian seas into the Black Sea, Nat. Geosci., 4, 4-11, 2012.

Barker, S., Knorr, G., Edwards, R. L., Parrenin, F., Putnam, A. E., Skinner, L. C., Wolff, E., and Ziegler, M.: 800,000 years of abrupt climate variability, Science, 334, 347-351, 2011.
Bazin, L., Landais, A., Lemieux-Dudon, B., Toyé Mahamadou Kele, H., Veres, D., Parrenin, F., Martinerie, P., Ritz, C., Capron, E., Lipenkov, V., Loutre, M.-F., Raynaud, D., Vinther, B., Svensson, A., Rasmussen, S. O., Severi, M., Blunier, T., Leuenberger, M., Fischer, H., Masson-Delmotte, V., Chappellaz, J., and Wolff, E.: An optimized multi-proxy, multi-site Antarctic ice and gas orbital chronology (AICC2012): 120-800 ka, Clim. Past, 9, 17151731, doi:10.5194/cp-9-1715-2013, 2013.

Bender, M., Sowers, T., and Labeyrie, L. D., The Dole effect and its variation during the last 130,000 years as measured in the Vostok core, Global Biogeochem. Cy., 8, 363-376, 1994.

Blaauw, M., Wohlfarth, B., Christen, J. A., Ampel, L., Veres, D., Hughen, K. A., Preusser, F., and Svensson, A.: Were last glacial climate events simultaneous between Greenland and France? A quantitative comparison using non-tuned chronologies, J. Quaternary Sci., 25, 387-394, 2010.

Blockley, S. P. E., Lane, C. S., Hardiman, M., Rasmussen, S. O., Seierstad, I. K., Steffensen, J. P., Svensson, A., Lotter, A. F., Turney, C. S. M., Bronk Ramsey, C., and INTIMATE members: Synchronisation of palaeoenvironmental records over the last 60,000 years, and an extended INTIMATE event stratigraphy to 48,000 b2k, Quaternary Sci. Rev., 36, 2-10, 2012.

Blunier, T. and Brook, E. J.: Timing of millennial-scale climate change in Antarctica and Greenland during the last glacial period, Science, 291, 109-112, 2001.

Blunier, T., Chappellaz, J., Schwander, J., Dällenbach, A., Stauffer, B., Stocker, T., Raynaud, D., Jouzel, J., Clausen, H., Hammer, C., and Johnsen, S.: Asynchrony of Antarctic and Greenland climate change during the last glacial period, Nature, 394, 739-743, 1998.

Blunier, T., Spahni, R., Barnola, J.-M., Chappellaz, J., Loulergue, L., and Schwander, J.: Synchronization of ice core records via atmospheric gases, Clim. Past, 3, 325-330, doi:10.5194/cp-3-3252007, 2007.

Boch, R., Cheng, H., Spötl, C., Edwards, R. L., Wang, X., and Häuselmann, Ph.: NALPS: a precisely dated European climate record 120-60 ka, Clim. Past, 7, 1247-1259, doi:10.5194/cp-71247-2011, 2011.

Braun, H., Ditlevsen, P., Kurths, J., and Mudelsee, M.: A twoparameter stochastic process for Dansgaard-Oeschger events, $\mathrm{Pa}-$ leoceanography, 26, PA3214, doi:10.1029/2011pa002140, 2011.

Bronk Ramsey, C., Staff, R. A., Bryant, C. L., Brock, F., Kitagawa, H., van der Plicht, J., Schlolaut, G., Marshall, M. H., Brauer, A., Lamb, H. F., Payne, R. L., Tarasov, P. E., Haraguchi, T., Gotanda, K., Yonenobu, H., Yokoyama, Y., Tada, R., and Nakagawa, T. A.: Complete Terrestrial Radiocarbon Record for 11.2 to 52.8 kyr B.P., Science, 338, 370-374, 2012.

Brook, E. J., Sowers, T., and Orchardo, J.: Rapid variations in atmospheric methane concentration during the past 110000 years, Science, 273, 1087-1091, 1996.

Buiron, D., Chappellaz, J., Stenni, B., Frezzotti, M., Baumgartner, M., Capron, E., Landais, A., Lemieux-Dudon, B., MassonDelmotte, V., Montagnat, M., Parrenin, F., and Schilt, A.: TALDICE-1 age scale of the Talos Dome deep ice core, East Antarctica, Clim. Past, 7, 1-16, doi:10.5194/cp-7-1-2011, 2011.

Buiron, D., Stenni, B., Chappellaz, J., Landais, A., Baumgartner, M., Bonazza, M., Capron, E., Frezzotti, M. Kageyama, M., Lemieux-Dudon, B., Masson-Delmotte, V., Parrenin, F., Schilt, A., Selmo, E., Severi, M., Swingedouw, D., and Udisti, R.: 
Regional imprints of millennial variability during the MIS 3 period around Antarctica, Quaternary Sci. Rev., 48, 99-112, 2012.

Caillon, N., Severinghaus, J. P., Jouzel, J., Barnola, J.-M., Kang, J., and Lipenkov, V. Y.: Timing of atmospheric $\mathrm{CO}_{2}$ and Antarctic temperature changes across Termination III, Science, 299, 17281731, 2003.

Capron, E., Landais, A., Lemieux-Dudon, B., Schilt, A., MassonDelmotte, V., Buiron, D., Chappellaz, J., Dahl-Jensen, D., Johnsen, S., and Leuenberger, M.: Synchronizing EDML and NorthGRIP ice cores using $\delta^{18} \mathrm{O}$ of atmospheric oxygen $\left(\delta^{18} \mathrm{O}_{\mathrm{atm}}\right)$ and $\mathrm{CH}_{4}$ measurements over MIS5 (80-123 kyr), Quaternary Sci. Rev., 29, 222-234, 2010.

Capron, E., Landais, A., Buiron, D., Cauquoin, A., Chappellaz, J., Debret, M., Jouzel, J., Leuenberger, M., Martinerie, P., MassonDelmotte, V., Mulvaney, R., Parrenin, F., and Prié, F.: Glacialinterglacial dynamics of Antarctic firn columns: comparison between simulations and ice core air- $\delta^{15} \mathrm{~N}$ measurements, Clim. Past, 9, 983-999, doi:10.5194/cp-9-983-2013, 2013.

Cheng, H., Edwards, R. L., Broecker, W. S., Denton, G. H., Kong, X., Wang, Y., Zhang, R., and Wang, X.: Ice Age Terminations, Science, 326, 248-252, doi:10.1126/science.1177840, 2009.

Chappellaz, J., Blunier, T., Raynaud, D., Barnola, J.-M., Schwander, J., and Stauffer, B.: Synchronous changes in atmospheric $\mathrm{CH}_{4}$ and Greenland climate between 40 and 8 kyr BP, Nature, 366, 443-445, 1993.

Dahl-Jensen, D., Mosegaard, K., Gundestrup, N., Clow, G. D., Johnsen, S. J., Hansen, A. W., and Balling, N.: Past temperatures directly from the Greenland ice sheet, Science, 282, 268-271, 1998.

Dansgaard, W., Clausen, H. B., Gundestrup, N., He, C. U., Johnsen, S. F., Kristinsdottir, P. M., and Reeh, N.: A new Greenland deep ice core, Science, 218, 1273-1277, 1982.

Dansgaard, W., Johnsen, S., Clausen, H. B., Dahl-Jensen, D., Gundestrup, N., Hammer, C. U., and Oeschger, H.: North Atlantic climatic oscillations revealed by deep Greenland ice cores, in: Climate processes and climate sensitivity, edited by: Hansen, J. E. and Takahashi, T., Am. Geophys. Union, Washington, 288298, 1984.

Dällenbach, A., Blunier, T., Flückiger, J., Stauffer, B., Chappellaz, J., and Raynaud, D.: Changes in the atmospheric $\mathrm{CH}_{4}$ gradient between Greenland and Antarctica during the Last Glacial and the transition to the Holocene, Geophys. Res. Lett., 27, 10051008, doi:200010.1029/1999GL010873, 2000.

Dreyfus, G. B., Parrenin, F., Lemieux-Dudon, B., Durand, G., Masson-Delmotte, V., Jouzel, J., Barnola, J.-M., Panno, L., Spahni, R., Tisserand, A., Siegenthaler, U., and Leuenberger, M.: Anomalous flow below $2700 \mathrm{~m}$ in the EPICA Dome $\mathrm{C}$ ice core detected using $\delta^{18} \mathrm{O}$ of atmospheric oxygen measurements, Clim. Past, 3, 341-353, doi:10.5194/cp-3-341-2007, 2007.

Drysdale, R. N., Zanchetta, G., Hellstrom, J. C., Fallick, A. E., McDonald, J., and Cartwright, I.: Stalagmite evidence for the precise timing of North Atlantic cold events during the early last glacial, Geology, 35, 77-80, 2007.

Dunbar, N. W., McIntosh, W. C., and Esser, R. P.: Physical setting and tephrochronology of the summit caldera ice record at Mount Moulton, West Antarctica, Geol. Soc. Am. Bull., 120, 796-812, 2008.

EPICA Community Members: Eight glacial cycles from an Antarctic ice core, Nature, 429, 623-628, 2004.
EPICA Community Members: One-to-one coupling of glacial climate variability in Greenland and Antarctica, Nature, 444, 195198, 2006.

Fleitmann, D., Cheng, H., Badertscher, S., Edwards, R. L., Mudelsee, M., Göktürk, O. M, Fankhauser, A., Pickering, R., Raible, C. C., Matter, A., Kramers, J., and Tüysüz, O.: Timing and climatic impact of Greenland interstadials recorded in stalagmites from northern Turkey, Geophys. Res. Lett., 36, L19707, doi:10.1029/2009GL040050, 2009.

Flückiger, J., Blunier, T., Stauffer, B., Chappellaz, J., Spahni, R., Kawamura, K., Schwander, J., Stocker, T. F., and Dahl-Jensen, D.: $\mathrm{N}_{2} \mathrm{O}$ and $\mathrm{CH}_{4}$ variations during the last glacial epoch: Insight into global processes, Global Biogeochem. Cy., 18, GB1020, doi:10.1029/2003GB002122, 2004.

Goujon, C., Barnola, J. M., and Ritz, C.: Modeling the densification of polar firn including heat diffusion: Application to close-off characteristics and gas isotopic fractionation for Antarctica and Greenland sites, J. Geophys. Res., 108, 101-1018, 2003.

Grootes, P. M., Stuiver, M., White, J. W. C., Johnsen, S. J., and Jouzel, J.: Comparison of the oxygen isotope records from the GISP2 and GRIP Greenland ice cores, Nature, 366, 552-554, 1993.

Huber, C., Leuenberger, M., Spahni, R., Flückiger, J., Schwander, J., Stocker, T., Johnsen, S., Landais, A., and Jouzel, J.: Isotope calibrated Greenland temperature record over Marine Isotope Stage 3 and its relation to $\mathrm{CH}_{4}$, Earth Planet. Sc. Lett., 243, 504 519, 2006.

Huybrechts, P., Rybak, O., Pattyn, F., Ruth, U., and Steinhage, D.: Ice thinning, upstream advection, and non-climatic biases for the upper $89 \%$ of the EDML ice core from a nested model of the Antarctic ice sheet, Clim. Past, 3, 577-589, doi:10.5194/cp-3577-2007, 2007.

Jouzel, J., Masson-Delmotte, V., Cattani, O., Dreyfus, G., Falourd, S., Hoffmann, G., Minster, B., Nouet, J., Barnola, J. M., Chappellaz, J., Fischer, H., Gallet, J. C., Johnsen, S., Leuenberger, M., Loulergue, L., Luethi, D., Oerter, H., Parrenin, F., Raisbeck, G., Raynaud, D., Schilt, A., Schwander, J., Selmo, E., Souchez, R., Spahni, R., Stauffer, B., Steffensen, J. P., Stenni, B., Stocker, T. F., Tison, J. L., Werner, M., and Wolff, E. W.: Orbital and Millennial Antarctic climate variability over the past 800,000 years, Science, 317, 793-796, 2007.

Kawamura, K., Parrenin, F., Lisiecki, L., Uemura, R., Vimeux, F., Severinghaus, J. P., Hutterli, M. A., Nakazawa, T., Aoki, S., Jouzel, J., Raymo, M. E., Matsumoto, K., Hisakazu, N., Motoyama, H., Fujita, S., Goto-Azuma, K., Fujii, Y., and Watanabe, O.: Northern Hemisphere forcing of climatic cycles in Antarctica over the past 360000 years, Nature, 448, 912-916, 2007.

Klauenberg, K., Blackwell, P. G., Buck, C. E., Mulvaney, R., Röthlisberger, R., and Wolff, E. W.: Bayesian Glaciological Modelling to quantify uncertainties in ice core chronologies, Quaternary Sci. Rev., 30, 2961-2975, 2011.

Köhler, P.: Rapid changes in ice core gas records - Part 1: On the accuracy of methane synchronisation of ice cores, Clim. Past Discuss., 6, 1453-1471, doi:10.5194/cpd-6-1453-2010, 2010.

Landais, A., Caillon, N., Goujon, C., Grachev, A. M., Barnola, J. M., Chappellaz, J., Jouzel, J., Masson-Delmotte, V., and Leuenberger, M.: Quantification of rapid temperature change during DO event 12 and phasing with methane inferred from air isotopic measurements, Earth Planet. Sc. Lett., 225, 221-232, 2004. 
Landais, A., Barnola, J., Kawamura, K., Caillon, N., Delmotte, M., Ommen, T. V., Dreyfus, G., Jouzel, J., Masson-Delmotte, V., Minster, B., Freitag, J., Leuenberger, M., Schwander, J., Huber, C., Etheridge, D., and Morgan, V.: Firn-air $\delta^{15} \mathrm{~N}$ in modern polar sites and glacial-interglacial ice: a model-data mismatch during glacial periods in Antarctica?, Quaternary Sci. Rev., 25, 49-62, 2006.

Landais, A., Dreyfus, G., Capron, E., Masson-Delmotte, V., Sanchez-Goñi, M. F., Desprat, S., Hoffmann, G., Jouzel, J., Leuenberger, M., and Johnsen, S.: What drives the millennial and orbital variations of $\delta^{18} \mathrm{O}_{\mathrm{atm}}$ ?, Quaternary Sci. Rev., 29, 235246, 2010

Lang, C., Leuenberger, M., Schwander, J., and Johnsen, S.: $16^{\circ} \mathrm{C}$ Rapid temperature variation in Central Greenland 70,000 years ago, Science, 286, 934-937, 1999.

Legrand, M. and Mayewski, P.: Glaciochemistry of polar ice cores: A review, Rev. Geophys., 35, 219-243, doi:10.1029/96RG03527, 1997.

Lemieux-Dudon, B., Blayo, E., Petit, J. R., Waelbroeck, C., Svensson, A., Ritz, C., Barnola, J. M., Narcisi, B. M., and Parrenin, F.: Consistent dating for Antarctic and Greenland ice cores, Quaternary Sci. Rev., 29, 8-20, 2010.

Lisiecki, L. E. and Raymo, M. E.: A Pliocene-Pleistocene stack of 57 globally distributed benthic $\Delta^{18} \mathrm{O}$ records, Paleoceanography, 20, PA1003, doi:10.1029/2004pa001071, 2005.

Loulergue, L.: Contraintes chronologiques et biogeochimiques grace au methane dans la glace naturelle: une application aux forages du projet EPICA, 2007, Ph.D. thesis, UJF, France, 2007.

Loulergue, L., Parrenin, F., Blunier, T., Barnola, J.-M., Spahni, R., Schilt, A., Raisbeck, G., and Chappellaz, J.: New constraints on the gas age-ice age difference along the EPICA ice cores, 0-50 kyr, Clim. Past, 3, 527-540, doi:10.5194/cp-3-527-2007, 2007.

Loulergue, L., Schilt, A., Spahni, R., Masson-Delmotte, V., Blunier, T., Lemieux, B., Barnola, J. M., Raynaud, D., Stocker, T. F., and Chappellaz, J.: Orbital and millennial-scale features of atmospheric $\mathrm{CH}_{4}$ over the past 800000 years, Nature, 453, 383-386, 2008.

Masson-Delmotte, V., Jouzel, J., Landais, A., Stievenard, M., Johnsen, S., White, J. W. C., Werner, M., Sveinbjornsdottir, A., and Fuhrer, K.: Rapid and slow reorganisation of the Northern Hemisphere hydrological cycle during the last glacial period as derived from the GRIP ice core deuterium-excess record, Science, 309, 118-121, 2005.

Mitchell, L. E., Brook, E. J., Sowers, T., McConnell, J. R., and Taylor, K.: Multidecadal variability of atmospheric methane, 1000-1800 C.E., J. Geophys. Res., 116, G02007, doi:10.1029/2010jg001441, 2011.

Narcisi, B., Petit, J. R., and Tiepolo, M.: A volcanic marker (92 ka) for dating deep East Antarctic ice cores, Quaternary Sci. Rev., 25, 2682-2687, 2006.

NGRIP Community Members: High-resolution record of Northern Hemisphere climate extending into the last interglacial period, Nature, 431, 147-151, doi:10.1038/nature02805, 2004.

Parrenin, F., Jouzel, J., Waelbroeck, C., Ritz, C., and Barnola, J.-M.: Dating the Vostok ice core by an inverse method, J. Geophys. Res., 106, 31837-31852, doi:10.1029/2001JD900245, 2001.

Parrenin, F., Remy, F., Ritz, C., Siegert, M. J., and Jouzel, J.: New modeling of the Vostok ice flow line and implication for the glaciological chronology of the Vostok ice core, J. Geophys. Res,
109, 1-14, 2004.

Parrenin, F., Barnola, J.-M., Beer, J., Blunier, T., Castellano, E., Chappellaz, J., Dreyfus, G., Fischer, H., Fujita, S., Jouzel, J., Kawamura, K., Lemieux-Dudon, B., Loulergue, L., MassonDelmotte, V., Narcisi, B., Petit, J.-R., Raisbeck, G., Raynaud, D., Ruth, U., Schwander, J., Severi, M., Spahni, R., Steffensen, J. P., Svensson, A., Udisti, R., Waelbroeck, C., and Wolff, E.: The EDC3 chronology for the EPICA Dome C ice core, Clim. Past, 3, 485-497, doi:10.5194/cp-3-485-2007, 2007.

Parrenin, F., Petit, J.-R., Masson-Delmotte, V., Wolff, E., BasileDoelsch, I., Jouzel, J., Lipenkov, V., Rasmussen, S. O., Schwander, J., Severi, M., Udisti, R., Veres, D., and Vinther, B. M.: Volcanic synchronisation between the EPICA Dome $\mathrm{C}$ and Vostok ice cores (Antarctica) 0-145 kyr BP, Clim. Past, 8, 1031-1045, doi:10.5194/cp-8-1031-2012, 2012a.

Parrenin, F., Barker, S., Blunier, T., Chappellaz, J., Jouzel, J., Landais, A., Masson-Delmotte, V., Schwander, J., and Veres, D.: On the gas-ice depth difference ( $\Delta$ depth) along the EPICA Dome C ice core, Clim. Past, 8, 1239-1255, doi:10.5194/cp-8-12392012, 2012b.

Parrenin, F., Masson-Delmotte, V., Köhler, P., Raynaud, D., Paillard, D., Schwander, J., Barbante, C., Landais, A., Wegner, A., and Jouzel, J.: Synchronous Change of Atmospheric $\mathrm{CO}_{2}$ and Antarctic Temperature During the Last Deglacial Warming, Science, 339, 1060-1063, 2013.

Pedro, J. B., van Ommen, T. D., Rasmussen, S. O., Morgan, V. I., Chappellaz, J., Moy, A. D., Masson-Delmotte, V., and Delmotte, M.: The last deglaciation: timing the bipolar seesaw, Clim. Past, 7, 671-683, doi:10.5194/cp-7-671-2011, 2011.

Petit, J. R., Jouzel, J., Raynaud, D., Barkov, N. I., Barnola, J. M., Basile, I., Bender, M., Chappellaz, J., Davis, M., Delaygue, G., Delmotte, M., Kotlyakov, V. M., Legrand, M., Lipenkov, V. Y., Lorius, C., Pépin, L., Ritz, C., Saltzman, E., and Stievenard, M.: Climate and atmospheric history of the past 420000 years from the Vostok ice core, Antarctica, Nature, 399, 429-436, 1999.

Raisbeck, G. M., Yiou, F., Jouzel, J., and Stocker, T. F.: Direct north-south synchronization of abrupt climate change record in ice cores using Beryllium 10, Clim. Past, 3, 541-547, doi:10.5194/cp-3-541-2007, 2007.

Rasmussen, S. O., Andersen, K. K., Svensson, A. M., Steffensen, J. P., Vinther, B. M., Clausen, H. B., Siggaard-Andersen, M., Johnsen, S. J., Larsen, L. B., Dahl-Jensen, D., Bigler, M., Rothlisberger, R., Fischer, H., Goto-Azuma, K., Hansson, M. E., and Ruth, U.: A new Greenland ice core chronology for the last glacial termination, J. Geophys. Res., 111, D06102, doi:10.1029/2005jd006079, 2006.

Rasmussen, S. O., Seierstad, I. K., Andersen, K. K., Bigler, M., Dahl-Jensen, D., and Johnsen, S. J.: Synchronization of the NGRIP, GRIP, and GISP2 ice cores across MIS 2 and palaeoclimatic implications, Quaternary Sci. Rev., 27, 18-28, 2008.

Ruth, U., Barnola, J.-M., Beer, J., Bigler, M., Blunier, T., Castellano, E., Fischer, H., Fundel, F., Huybrechts, P., Kaufmann, P., Kipfstuhl, S., Lambrecht, A., Morganti, A., Oerter, H., Parrenin, F., Rybak, O., Severi, M., Udisti, R., Wilhelms, F., and Wolff, E.: "EDML1": a chronology for the EPICA deep ice core from Dronning Maud Land, Antarctica, over the last 150000 years, Clim. Past, 3, 475-484, doi:10.5194/cp-3-475-2007, 2007. 
Schilt, A., Baumgartner, M., Blunier, T., Schwander, J., Spahni, R., Fischer, H., and Stocker, T. F.: Glacial-interglacial and millennial-scale variations in the atmospheric nitrous oxide concentration during the last 800,000 years, Quaternary Sci. Rev., 29, 182-192, 2010.

Schüpbach, S., Federer, U., Bigler, M., Fischer, H., and Stocker, T. F.: A refined TALDICE-1a age scale from 55 to $112 \mathrm{ka}$ before present for the Talos Dome ice core based on highresolution methane measurements, Clim. Past, 7, 1001-1009, doi:10.5194/cp-7-1001-2011, 2011.

Schwander, J., Sowers, T., Barnola, J. M., Blunier, T., Fuchs, A., and Malaizé, B.: Age scale of the air in the summit ice: implication for glacial-interglacial temperature change, J. Geophys. Res., 102, 19483-19493, 1997.

Severi, M., Becagli, S., Castellano, E., Morganti, A., Traversi, R., Udisti, R., Ruth, U., Fischer, H., Huybrechts, P., Wolff, E., Parrenin, F., Kaufmann, P., Lambert, F., and Steffensen, J. P.: Synchronisation of the EDML and EDC ice cores for the last 52 kyr by volcanic signature matching, Clim. Past, 3, 367-374, doi:10.5194/cp-3-367-2007, 2007.

Severi, M., Udisti, R., Becagli, S., Stenni, B., and Traversi, R.: Volcanic synchronisation of the EPICA-DC and TALDICE ice cores for the last $42 \mathrm{kyr}$ BP, Clim. Past, 8, 509-517, doi:10.5194/cp-8509-2012, 2012.

Severinghaus, J. P., Sowers, T., Brook, E. J., Alley, R. B., and Bender, M. L.: Timing of abrupt climate change at the end of the Younger Dryas interval from thermally fractionated gases in polar ice, Nature, 391, 141-146, 1998.

Singer, B. S., Guillou, H., Jicha, B. R., Laj, C., Kissel, C., Beard, B. L., and Johnson, C. M.: ${ }^{40} \mathrm{Ar} /{ }^{39} \mathrm{Ar}, \mathrm{K}-\mathrm{Ar}$ and ${ }^{230} \mathrm{Th}-{ }^{238} \mathrm{U}$ dating of the Laschamp excursion: A radioisotopic tie-point for ice core and climate chronologies, Earth Planet. Sci. Lett., 286, 80-88, 2009.

Sowers, T., Bender, M., Raynaud, D., and Korotkevich, Y. S.: $\delta^{15} \mathrm{~N}$ of $\mathrm{N}_{2}$ in air trapped in polar ice: a tracer of gas transport in the firn and a possible constraint on ice age-gas age differences, J. Geophys. Res., 97, 15683-15697, 1992.

Spahni, R., Schwander, J., Flückinger, J., Stauffer, B., Chapellaz, J., and Raynaud, D.: The attenuation of fast atmospheric $\mathrm{CH}_{4}$ variations recorded in polar ice cores, Geophys. Res. Lett., 30, 1571, doi:10.1029/2003GL017093, 2003.

Spahni, R., Chappellaz, J., Stocker, T., Loulergue, L., Hausmmann, G., Kawamura, K., Flückiger, J., Schwander, J., Raynaud, D., Masson-Delmotte, V., and Jouzel, J.: Atmospheric Methane and Nitrous Oxide of the Late Pleistocene from Antarctic Ice Cores, Science, 310, 1317-1321, 2005.

Steig, E. J., Brook, E., White, J., and Sucher, C.: Synchronous Climate Changes in Antarctica and the North Atlantic, Science, 282, 92-95, 1998.

Stenni, B., Buiron, D., Frezzotti, M., Albani, S., Barbante, C., Bard, E., Barnola, J. M., Baroni, M., Baumgartner, M., Bonazza, M., Capron, E., Castellano, E., Chappellaz, J., Delmonte, B., Falourd, S., Genoni, L., Iacumin, P., Jouzel, J., Kipfstuhl, S., Landais, A., Lemieux-Dudon, B., Maggi, V., Masson-Delmotte, V., Mazzola, C., Minster, B., Montagnat, M., Mulvaney, R., Narcisi, B., Oerter, H., Parrenin, F., Petit, J. R., Ritz, C., Scarchilli, C., Schilt, A., Schüpbach, S., Schwander, J., Selmo, E., Severi, M., Stocker, T. F., and Udisti, R.: Expression of the bipolar seesaw in Antarctic climate records during the last deglaciation, Nat. Geosci., 4,
46-49, 2011.

Stocker, T. F. and Johnsen, S. J.: A minimum thermodynamic model for the bipolar seesaw, Paleoceanography, 18, PA000920, doi:10.1029/2003PA000920, 2003.

Suwa, M. and Bender, M. L.: Chronology of the Vostok ice core constrained by $\mathrm{O}_{2} / \mathrm{N}_{2}$ ratios of occluded air, and its implication for the Vostok climate records, Quaternary Sci. Rev., 27, 10931106, 2008.

Svensson, A., Andersen, K. K., Bigler, M., Clausen, H. B., DahlJensen, D., Davies, S. M., Johnsen, S. J., Muscheler, R., Parrenin, F., Rasmussen, S. O., Röthlisberger, R., Seierstad, I., Steffensen, J. P., and Vinther, B. M.: A 60000 year Greenland stratigraphic ice core chronology, Clim. Past, 4, 47-57, doi:10.5194/cp-4-472008, 2008.

Svensson, A., Bigler, M., Blunier, T., Clausen, H. B., Dahl-Jensen, D., Fischer, H., Fujita, S., Goto-Azuma, K., Johnsen, S. J., Kawamura, K., Kipfstuhl, S., Kohno, M., Parrenin, F., Popp, T., Rasmussen, S. O., Schwander, J., Seierstad, I., Severi, M., Steffensen, J. P., Udisti, R., Uemura, R., Vallelonga, P., Vinther, B. M., Wegner, A., Wilhelms, F., and Winstrup, M.: Direct linking of Greenland and Antarctic ice cores at the Toba eruption (74 ka BP), Clim. Past, 9, 749-766, doi:10.5194/cp-9-749-2013, 2013.

Udisti, R., Becagli, S., Castellano, E., Delmonte, B., Jouzel, J., Petit, J.-R., Schwander, J., Stenni, B., and Wolff, E. W.: Stratigraphic correlations between the EPICA-Dome $\mathrm{C}$ and Vostok ice cores showing the relative variations of snow accumulation over the past 45 kyr, J. Geophys. Res., 109, D08101, doi:10.1029/2003jd004180, 2004.

Vallelonga, P., Bertagna, G., Blunier, T., Kjær, H. A., Popp, T. J., Rasmussen, S. O., Steffensen, J. P., Stowasser, C., Svensson, A. S., Warming, E., Winstrup, M., Bigler, M., and Kipfstuhl, S.: Duration of Greenland Stadial 22 and ice-gas $\Delta$ age from counting of annual layers in Greenland NGRIP ice core, Clim. Past, 8, 1839-1847, doi:10.5194/cp-8-1839-2012, 2012.

Voelker, A. H. L.: Global distribution of centennial-scale records for Marine Isotope Stage (MIS) 3: a database, Quaternary Sci. Rev., 21, 1185-1212, 2002.

Vinther, B. M., Clausen, H. B., Johnsen, S. J., Rasmussen, S. O., Andersen, K. K., Buchardt, S. L., Dahl-Jensen, D., Seierstad, I. K., Siggaard-Andersen, M., Steffensen, J. P., Svensson, A., Olsen, J., and Heinemeier, J.: A synchronized dating of three Greenland ice cores throughout the Holocene, J. Geophys. Res., 111, D13102, doi:10.1029/2005jd006921, 2006.

Vinther, B. M., Clausen, H. B., Kipfstuhl, S., Fischer, H., Bigler, M., Oerter, H., Wegner, A., Wilhelms, F., Severi, M., Udisti, R., Beer, J., Steinhilber, F., Muscheler, R., Rasmussen, S. O., and Svensson, A.: An annual layer counted EDML time scale covering the past 16700 years, Geophysical Research Abstracts, 14, EGU2012-13043, 2012.

Waelbroeck, C., Frank, N., Jouzel, J., Parrenin, F., MassonDelmotte, V., and Genty, D.: Transferring radiometric dating of the last interglacial sea level high stand to marine and ice core records, Earth Planet. Sci. Lett., 265, 183-194, 2008.

Wang, Y. J., Cheng, H., Edwards, R. L., Kong, X., Shao, X., Chen, S., Wu, J., Jiang, X., Wang, X., and An, Z.: Millennial- and orbital-scale changes in the East Asian monsoon over the past 224,000 years, Nature, 451, 1090-1093, 2008. 
Wolff, E. W., Fischer, H., and Röthlisberger, R., Glacial terminations as southern warmings without northern control, Nat. Geosci., 2, 206-209, 2009.

Wolff, E. W., Chappellaz, J., Blunier, T., Rasmussen, S. O., and Svensson, A.: Millennial-scale variability during the last glacial: The ice core record, Quaternary. Sci. Rev., 29, 2828-2838, 2010.
Yiou, F., Raisbeck, G. M., Baumgartner, S., Beer, J., Hammer, C., Johnsen, S., Jouzel, J., Kubik, P. W., Lestringuez, J., Stiévenard, M., Suter, M., and Yiou, P.: Beryllium 10 in the Greenland Ice Core Project ice core at Summit, Greenland, J. Geophys. Res., 102, 26783-26794, 1997.

Zielinski, G. A.: Use of paleo-records in determining variability within the volcanism-climate system, Quaternary Sci. Rev., 19, 417-438, 2000. 